\title{
БЕТОНИ НА ЗМІШАНОМУ ЗАПОВНЮВАЧІ ТА СТРУКТУРОВАНІЙ ПОЛІСПИРТОМ ВОДІ
}

\section{CONCRETES ON MIXED FILLER AND STRUCTURED POLYSPIRT WATER}

\section{Шишкіна О.О. канд. техн. наук, доц. (Криворізький національний університет, м. Кривий Ріг) \\ Shishkina OO Cand. tech. Sciences, Associate Professor (Kryvyi Rih National University, Kryvyi Rih)}

Наведено результати досліджень дрібнозернистих бетонів, виготовлених із використанням у якості заповнювача суміші квариового піску та продукту подрібнення гірських порід, які містять залізо. Для наноактивації бетонів використана вода, структурована поліспиртом у надмалій конщентраиії.

One of the effective materials for the manufacture of roads and hydraulic structures, which is quite resistant to environmental influences, is concrete based on Portland cement. The advantages of building roads with cement-concrete pavement are obvious. However, it has significant shortcomings, and due to the lack of specialists in this field, builders have distrust and even fear of such construction. Therefore the main question remains unresolved: how in this case to reduce risks and to provide necessary quality of coverings from monolithic cement concrete. Among the many factors influencing the strength of concrete, this paper examines the influence of qualitative and quantitative composition of aggregates in the presence of polyalcohol in ultra-low concentrations. The aim of the research was to obtain concrete with increased compressive strength and speed of its formation due to the use of polyalcohol and mixed fine aggregate. To achieve this goal it is necessary to solve the following tasks: to determine the degree of influence of polyalcohol on the compressive strength of finegrained concrete on a mixed aggregate; determine the optimal ratio between the components of the specified concrete. The results of studies of the impact of the content of iron ore beneficiation in the fine aggregate of fine-grained concrete showed that firstly there is their optimal content in the aggregate, and secondly the introduction of polyalcohol into the concrete increases its strength, but the presence of waste from mining and processing plants the degree of increase in strength, which remains quite high. As the results of experiments show, when the content of waste from mining and processing plants in the aggregate in the amount of $30 \ldots 40 \%$, the maximum increase in concrete strength is achieved. The concentration of the polyscohol solution, which provides the maximum increase in the strength of concrete is in the range of $0.004 \ldots$ $0.006 \mathrm{M}$.

Ключові слова: дрібнозернисті бетони, пісок, гірські породи, структурована вода, поліспирт.

Keywords: fine-grained concrete, sand, rocks, structured water, polyalcohol. 


\section{Постановка проблеми}

На матеріал, з якого виготовляють верхній шар дорожнього полотна й гідротехнічні споруди, впливає навколишнє середовище, змінюючи його фізико-механічні властивості, i, як наслідок, впливає на його довговічність.

Одним 3 ефективних матеріалів для виготовлення дорожнього полотна й гідротехнічних споруд, що досить добре протистоїть впливу навколишнього середовища, $є$ бетон на основі портландцементу. Переваги будівництва доріг із цементобетонним покриттям очевидні. Проте, він має істотні недоліки, а через відсутність фахівців у цій області в будівельників виникає недовіра й навіть острах такого будівництва. Тому невирішеним залишається головне питання: як у цьому випадку знизити ризики, i забезпечити необхідну якість покриттів із монолітного цементного бетону.

На цей час основним недоліком бетонів для виготовлення верхнього шару дорожнього $є$ недостатня міцність, та тріщиностійкість.

Тому завдання одержання дорожніх і гідротехнічних бетонів, які мають досить високу міцність та швидкість іï формування, становить значний науковий і практичний інтерес, а його рішення актуально. Серед багатьох факторів, що роблять вплив на міцність бетону, у даній статті досліджений вплив якісного й кількісного складу заповнювачів у присутності поліспирту в надмалих концентраціях.

\section{Аналіз відомих досліджень і публікацій}

На основі аналізу літературних даних було встановлена доцільність визначення та застосування оптимального співвідношення між крупним та дрібним заповнювачами бетону [1], а також дрібного заповнювача 3 відходів гірничо-збагачувальних комбінатів та змішаного дрібного заповнювача, який являє собою суміш річкового піску та дрібнозернистих відходів гірничо-збагачувальних комбінатів [2-6].

Відома модифікація структури бетону комплексною добавкою, що складається 3 поліспирту й колоїдної поверхнево-активної речовини (МПАР), розведеної до концентрації утворення дімерів, дозволяє одержати бетони, що володіють підвищеною міцністю та швидкістю її формування [7-9]. Однак дослідження одночасного впливу поліспирту та змішаного дрібного заповнювача на міцність бетону, яке має достатній науковий i практичний інтерес, на цей час не виконано

Метою проведених досліджень було одержання бетону з підвищеною міцністю при стиску та швидкістю її формування за рахунок застосування поліспирту та змішаного дрібного заповнювача.

Для досягнення поставленої мети необхідно вирішити такі задачі:

- визначити ступінь впливу поліспирту на міцність при стиску дрібнозернистого бетону на змішаному заповнювачі;

- визначити оптимальні співвідношення між компонентами означеного бетону. 
У дослідженнях для виготовлення бетону використовували портландцемент M400 (ПрАТ «Кривий Ріг цемент»), дрібний заповнювач відходи збагачення залізних руд Новокріворізького гірничозбагачувального комплексу ПрАТ «Арселор Міттал Кривий Ріг» (Україна) і дніпровський річковий пісок. Компоненти бетонної суміші дозували в необхідних, відповідно до плану експерименту, кількостях, перемішували лабораторному змішувачі протягом 3 хв. Отримана суміш укладалася в металеву форму-куб, який має розмір сторін 40х40x160 мм. Форму, що містить бетонну суміш жорстко закріплювали на лабораторному вібромайданчику й ущільнювали вібрацією до повного ущільнення, яке характеризувалося припиненням осідання бетонної суміші й припиненням виділення бульбашок повітря. Після завершення укладання й ущільнення бетонної суміші у формі, відкриту поверхню зразка загладжували кельмою. Перші 24 години зразки бетону тверділи в нормальних умовах, при цьому їх до розпалубки зберігали у формах, покритих вологою тканиною. Це виключало можливість випаровування 3 них вологи в приміщенні з температурою повітря $(293 \pm 5)$ К. Через 24 години після виготовлення, зразки бетону виймали 3 форм та поміщали в камеру, яка забезпечувала на їхній поверхні нормальні умови, тобто температуру (293 $\pm 3)$ К і відносну вологість повітря $(95 \pm 5) \%$. Основним показником якості досліджуваного бетону була прийнято межу його міцності при стиску. Визначення міцності зразків здійснювали за допомогою універсальної випробувальної машини УММ-100.

Результати досліджень впливу вмісту відходів збагачення залізних руд у складі заповнювача дрібнозернистих бетонів показали (рис. 1), що, поперше, $є$ їхній оптимальний уміст у заповнювачі, по-друге, введення поліспирту до складу бетону призводить до збільшення його міцності, але наявність відходів ГЗК декілька зменшує ступінь підвищення міцності (рис. 2), яка залишається достатньо високою.

Як показують результати дослідів, при вмісті відходів ГЗК у складі заповнювача в кількості $30 \ldots 40 \%$ досягається максимальне збільшення міцності бетону. Концентрація розчину поліспирту, яка забезпечує максимальне збільшення міцності бетону знаходиться в межах 0,004...0,006 М (рис. 3).

\section{Висновки}

Результати проведених досліджень дозволяють зробити наступні висновки:

1. Введення до складу дрібнозернистого бетону, який виготовлено на комплексному заповнювачі з річкового піску та відходів збагачення ГЗК поліспирту у вигляді розчину певної концентрації призводить до збільшення міцності бетону на 50..65\% по відношенню до міцності бетону аналогічного складу отриманого без додавання поліспирту. 
"Сучасні технології та методи розрахунків у будівництві", випуск 14, 2020

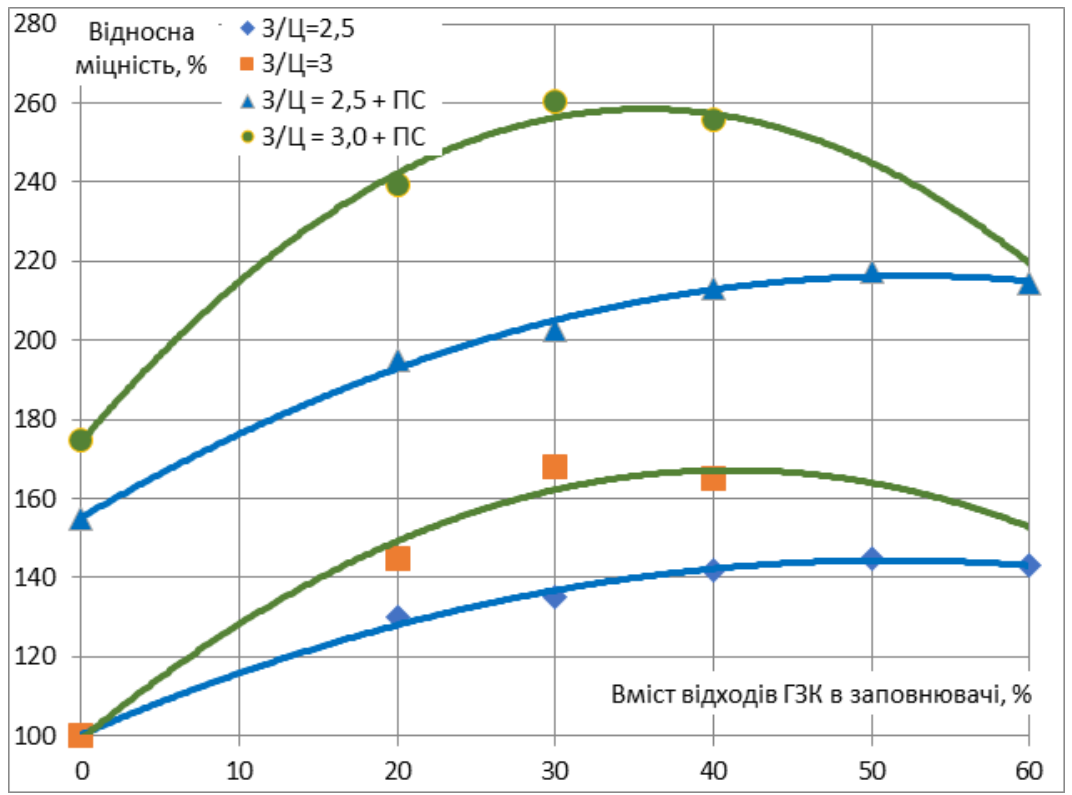

Рис. 1. Відносна міцність бетону

(концентрація розчину поліспирту (ПС) $0,0055 \mathrm{M}$ )

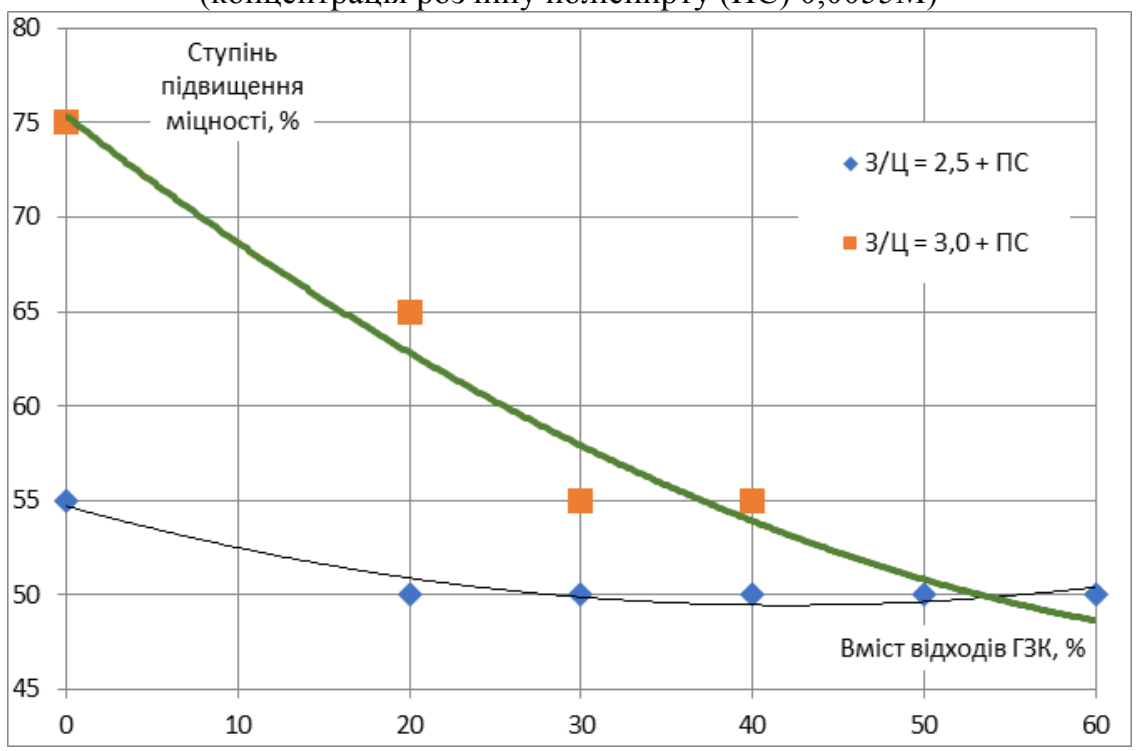

Рис. 2. Ступінь підвищення міцності бетону 


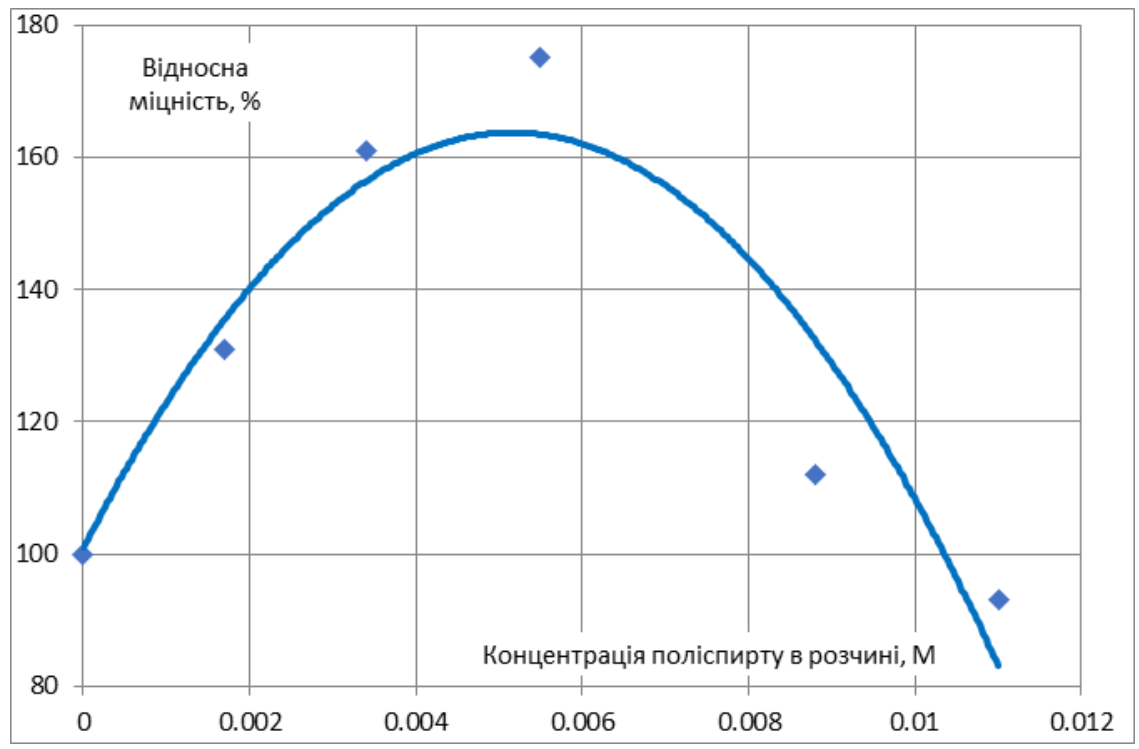

Рис. 3. Вплив концентрації поліспирту на міцність бетону

2. Оптимальна концентрація розчину поліспирту, яка забезпечує максимальне збільшення міцності бетону складає $0,004 \ldots 0,006 \mathrm{M}$.

3. Оптимальний вміст відходів ГЗК у заповнювачі складає $30 \ldots 40 \%$.

4. При збільшенні вмісту відходів ГЗК у складі заповнювача більше $60 \%$ ефективність застосування поліспирту втрачається.

\section{References}

1. Tolmachev S.N., Zaxarov D.S. Vlyyanye zapolnytelej na prochnost dorozhnыx betonov // Visnyk Odeskoyi derzhavnoyi akademiyi budivnycztva ta arxitektury, 2016. 63. S. 191-196.

2. Puxalskyj G. V. Svojstva betonov na peskax yz otxodov gornoobogatytel kombynatov / G.V. Puxalskyj, G.N. Bondarenko // Beton y zhelezobeton. 1975. - 5. - S. 26-28.

3. Shyshkyn A.A. Osobennosty yspolzovanye otxodov gornoobogatytel kombynatov v proyzvodstve stroytel materyalov / A. A. Shyshkyn, A. A. Shyshkyna, V. V. Shherba // Visnyk DNABA. 2013. - 1(99). - S. 8-12.

4. Vandolovskyj A. G. Micznisni vlastyvosti osoblyvo dribnozernystogo betonu na vidxodax girnycho-zbaachuvalnyx kombinativ u roli zapovnyuvacha / A.G. Vandolovskyj, V.M. Chajka // Zbirnyk naukovyxpracz UkrDUZT, 2016. - 160. - S. 1724.

5. Shyshkin O.O. Reakcijni poroshkovi betony na zmishanomu zapovnyuvachi / O.O. Shyshkin, Xalid Eddin // Suchasni texnologiyi ta metody rozraxunkiv v budivnycztvi. Luczk. 2017. 8. S. 277-285 
6. Shherba V.V. Dribnozernystyj beton na modyfikovanomu gipsocementnomu vyazhuchomu / V.V.Shherba, O.O. Shyshkin, O.O.Shyshkina // Suchasne promyslove ta cyvilne budivnycztvo. 2014. tom 10. 1. S. 41-48.

7. Shishkina A. Shishkin A.Research into effect of complex nanomodifiers on the strength of fine-grained concrete / A. Shishkina A. Shishkin //Eastern-European Journal of Enterprise Technologies. 2018. 2/6 (92). pp. 29 - 33.

8. Shyshkina O.O. Doslidzhennya vply`vu koloyidny`x poverxnevo-akty`vny`x rechovy`n na strukturoutvorennya dribnozerny`sty`x betoniv betonu / O.O. Shyshkina // Suchasni texnologiyi ta metody rozraxunkiv u budivnycztvi, 2019. 11. S. $193-204$.

9. Shyshkina O.O. Doslidzhennya vplyvu micelyarnogo katalizu na micznist luzhnogo reakcijnogo poroshkovogo betonu / O.O. Shyshkina // Suchasni texnologiyi ta metody rozraxunkiv u budivnycztvi. 2018.10.212-218

\section{Список використаної літератури}

1. Толмачев С.Н., Захаров Д.С. Влияние заполнителей на прочность дорожных бетонов // Вісник Одеської державної академії будівництва та архітектури, 2016. 63. С. 191-196.

2. Пухальский Г. В. Свойства бетонов на песках из отходов горнообогатительных комбинатов / Г.В. Пухальский, Г.Н. Бондаренко // Бетон и железобетон. 1975. - № 5. - С. 26-28.

3. Шишкин А.А. Особенности использования отходов горнообогатительных комбинатов в производстве строительных материалов / А. А. Шишкин, А. А. Шишкина, В. В. Щерба // Вісник ДНАБА. 2013. - 1(99). - С. 8-12.

4. Вандоловский А. Г. Міцнісні властивості особливо дрібнозернистого бетону на відходах гірничо-збагачувальних комбінатів у ролі заповнювача / А.Г. Вандоловский, В.М. Чайка // Збірник наукових праць УкрДУЗТ, 2016. - вып. 160. C. 17-24.

5. Шишкін О.О. Реакційні порошкові бетони на змішаному заповнювачі / О.О. Шишкін, Халід Еддін // Сучасні технології та методи розрахунків в будівництві. Луцк. 2017. 8. С. 277-285

6. Щерба В.В. Дрібнозернистий бетон на модифікованому гіпсоцементному в'яжучому / В.В.Щерба, О.О. Шишкін, О.О.Шишкіна // Сучасне промислове та цивільне будівництво. 2014. том 10. 1. С. 41-48.

7. Shishkina A. Shishkin A.Research into effect of complex nanomodifiers on the strength of fine-grained concrete / A. Shishkina A. Shishkin //Eastern-European Journal of Enterprise Technologies. 2018. 2/6 (92). C. $29-33$.

8. Шишкіна О.О. Дослідження впливу колоїдних поверхнево-активних речовин на структуроутворення дрібнозернистих бетонів бетону / О.О. Шишкіна // Сучасні технології та методи розрахунків у будівництві, 2019. 11. С. $193-204$.

9. Шишкіна О.О. Дослідження впливу міцелярного каталізу на міцність лужного реакційного порошкового бетону / О.О. Шишкіна // Сучасні технології та методи розрахунків у будівництві. 2018.10.212-218. 